\title{
THE IMPLEMENTATION OF PROPHETIC VALUES TO MAINTAIN JOURNALIST PROFESSIONALISM
}

\author{
Fikry Zahria Emeraldien', Rahma Sugihartati², Dwiki Iqbal'3 , Qhoirun Annisa4, \\ Putri Ardelia ${ }^{5}$ \\ 1,2Airlangga University, 3,4,5Sunan Ampel State Islamic University \\ 1fikry.zahria.emeraldien-2019@fisip.unair.ac.id, ${ }^{2}$ rahma.sugihartati@fisip.unair.ac.id, \\ 3dwiki11048@gmail.com, qannisa04@gmail.com, 5ardeliaputrii14@gmail.com
}

\begin{abstract}
Campus media is a place for students to develop their potential in the journalism field. Students who are agents of change not only provide quality news but also provide moral value in the news production process. Quality news can be raised through the role of a journalist in writing news (information). Prophetic journalism is a journalistic concept taken from the nature of the prophets. In this paper, we examine the application of the concept of prophetic journalism -journalism that imitates the prophetic characteristics of the Prophet Muhammad- among campus journalists. Prophet Muhammad is known for his four characteristics: șiddī $q$ (delivering accurate information), amānah (trustworthy as a source of information), tablïgh (delivering information in its entirety), fatānah (a journalist is required to be smart in revealing the truth of the news). The data from this study is the result of observations from the daily life of the researchers when carrying out the news production process with other campus journalists ranging from electronic media (radio \& television), print and online. The results of this study indicate that campus journalists at UIN Sunan Ampel Surabaya apply prophetic journalism well. By implementing the prophetic characteristics of the Prophet Muhammad when carrying out journalistic activities, journalists can maintain the professionalism of journalists. By using ethnographic research methods or commonly referred to as field research, researchers make observations as the main data and are equipped with in-depth interviews with several campus journalists. We also propose the nature of Prophet Ibrahim to be incorporated into the concept of prophetic journalism as well. Prophet Ibrahim is known for the story of his courage to seek the truth and reveal it when everyone was against it. This courage is important in supporting journalistic activities among students and professionals.
\end{abstract}

Keywords: Journalism; prophetic journalism; campus journalist.

Abstrak: Media kampus merupakan wadah bagi mahasiswa untuk mengembangkan potensinya di bidang jurnalistik. Mahasiswa yang menjadi agen perubahan tidak hanya memberikan berita yang berkualitas tetapi juga memberikan nilai moral dalam proses produksi berita. Berita yang berkualitas dapat diangkat melalui peran seorang jurnalis dalam menulis berita/informasi. Jurnalisme profetik merupakan konsep jurnalistik yang diambil dari fitrah para nabi. Dalam tulisan ini, kami mengkaji penerapan konsep jurnalisme profetik -jurnalisme yang meniru sifat profetik Nabi Muhammad- di kalangan jurnalis kampus. Nabi Muhammad dikenal dengan empat karakteristiknya: șiddīq (menyampaikan informasi yang akurat), amānah (dapat dipercaya sebagai sumber informasi), tabligh (menyampaikan informasi secara keseluruhan), fathanah (wartawan dituntut untuk cerdas dalam mengungkapkan kebenaran berita). berita). Data dari penelitian ini merupakan hasil observasi dari keseharian peneliti saat melakukan proses produksi berita bersama wartawan kampus lainnya mulai dari media elektronik (radio \& televisi), cetak dan online. Hasil penelitian ini menunjukkan bahwa jurnalis kampus di UIN Sunan Ampel Surabaya menerapkan jurnalisme profetik 
dengan baik. Dengan menerapkan sifat-sifat kenabian Nabi Muhammad SAW saat melakukan kegiatan jurnalistik, jurnalis dapat menjaga profesionalisme jurnalis. Dengan menggunakan metode penelitian etnografi atau biasa disebut penelitian lapangan, peneliti menjadikan observasi sebagai data utama dan dilengkapi dengan wawancara mendalam dengan beberapa wartawan kampus. Kami juga mengusulkan sifat Nabi Ibrahim untuk dimasukkan ke dalam konsep jurnalisme profetik juga. Nabi Ibrahim dikenal dengan kisah keberaniannya untuk mencari kebenaran dan mengungkapkannya ketika semua orang menentangnya. Keberanian ini penting dalam mendukung kegiatan jurnalistik di kalangan mahasiswa dan profesional.

Kata kunci: Jurnalisme, jurnalistik profetik; jurnalis kampus.

\section{A. Introduction}

Prophetic journalism is a concept which has been widely studied in various perspectives, from communication, anthropology, to Islam. Some researchers who study this concept highlight that prophetic journalism is based on the four prophetic traits of the Prophet Muhammad, namely Șiddīq, amānah, tablīgh, and fațānah ${ }^{123}$. However, among these researchers, no one has discussed the prophetic characteristic of Prophet Ibrahim as part of prophetic journalism, even though it is essential. For this reason, this research is present in order to complete the four prophetic traits that are included in the concept of prophetic journalism.

Ramli introduced the concept of prophetic journalism as a journalistic practice based on the four characteristics of the Prophet Muhammad4. These prophetic traits include: șiddī (delivering accurate information), amānah (trustworthy as a source of information), tabligh (delivering information in its entirety), fațanah (a journalist is required to be smart in revealing the truth of the news). In addition, journalists are expected to be able to think intelligently and think critically in carrying out their roles, because journalists are sources of information that can influence society from all aspects. Therefore, a journalist must be careful in conveying news in order to build a positive contribution to society.

Prophetic journalism is a journalistic culture formed by Islamic values from an Islamic point of view, namely honesty and truth (șiddī and haq), messengers (tabligh), seeking solutions for the public interest (maslahah), and moderation (wasathiyyah) ${ }^{5}$. Prophet Muhammad, in the course of his da'wa, once sent a letter to the tribal chief in Medina containing a message to live towards the path of truth. From this story, Prophet Muhammad gave an example of the practice of journalistic activities by emphasizing the content of messages that invite goodness ${ }^{6}$. Therefore, journalism is a da'wa in Islam.

Prophetic has a close relationship with something constructive. Prophetic is defined as how a journalist is able to build a society without any confrontation, but to create something constructive in it. Journalists in Muslim-majority countries consider themselves to have an

\footnotetext{
${ }^{1}$ Nurhaya Muchtar et al., "Journalism and the Islamic Worldview: Journalistic Roles in Muslim-Majority Countries," Journalism Studies 18, no. 5 (2017): 555-575.

${ }^{2}$ Feri Purnama, "Pemikiran Parni Hadi Tentang Jurnalisme," Communicatus: Jurnal Ilmu komunikasi 3, no. 1 (2019): 33-48.

${ }^{3}$ Janet Steele, “Journalism and 'The Call to Allah': Teaching Journalism in Indonesia's Islamic Universities and State Institutes," International Journal of Communication 6, no. 0 (2012): 18.

${ }^{4}$ Ramli, "DAKWAH DAN JURNALISTIK ISLAM (Perspektif Dakwah Islamiyah)," KOMUNIDA: Media Komunikasi dan Dakwah 5, no. 1 (2015): 13837-138660-30.

${ }^{5}$ Muchtar et al., "Journalism and the Islamic Worldview: Journalistic Roles in Muslim-Majority Countries."

${ }^{6}$ M. Yoserizal Saragih, "Some Characteristics of Islamic Journalism Based on Al Quran," Budapest International Research and Critics Institute (BIRCI-Journal) : Humanities and Social Sciences 1, no. 1 (2018): $1-10$.
} 
important role as agents of change $\mathrm{e}^{7}$. Journalists can become educators and teachers who provide positive information and encourage people to do good. The results of this study show how important the journalist's approach to phenomena that occur in society is.

The aforementioned explanation is in line with Islamic journalism written by Ramli, where the reporting process based on Islamic values is essential ${ }^{8}$. According to him, a journalist who delivers news is the same as preaching. In Islam, this is called da'wa bil qolam. Ramli emphasized that a journalist has a role as an educator, straightener of information, the latest source, unifier and enforcer. Therefore, the information conveyed must contain a message of goodness and truth $^{9}$. Journalists must provide balanced reports and information. According to him, journalists in practice must seek the truth, with courage and conviction. Journalists must implement their duties based on Islamic principles, namely siddiq (honesty) and justice.

Hadi has the same opinion that prophetic journalism puts forward the aspect of truth ${ }^{10}$. All forms of journalistic practice must be carried out in accordance with the rules, namely conveying events or information according to facts to the wider community. Prophetic journalism is journalism that refers to the nature of the Prophet Muhammad who was honest, gave information intelligently, prioritized justice and truth ${ }^{11}$. These journalistic qualities are also stated in Alquran, namely: fair, accurate, responsible, and constructive criticism ${ }^{12}$.

Justice is a characteristic of Islam which is a journalistic ethic. God commands Muslims to uphold the principles of fair conduct to avoid disputes with anyone, including people who do not embrace Islam. A fair journalist is a journalist who can speak the truth, presents all sides of the story, does not harm, and can be responsible for what is conveyed. Fair in Islam's view is universal and can be applied universally, for example, journalists must be able to report on the situation of the two majority and minority groups. Not only reporting on the majority group, because this action can create peace journalism, namely journalist activities that create peaceful environmental conditions and do not carry elements of provocation. In Islamic principles, journalists are not allowed to try to spread rumors that are not certain, slander, and reveal the identity of the person concerned. Journalists must be critical of news sources, verify well, include documentary evidence, if possible, can include testimony, report in the right context and treat the subject fairly ${ }^{13}$.

Journalists must view accuracy as a critical aspect of their role in disseminating information to the public which is closely related to other important concepts such as truth, factuality, and credibility. Accuracy raises epistemological questions about what and how journalism is able to describe reality accurately, honestly, and based on facts. Moreover, accuracy forces journalists not only to base their reports on facts but also to verify whether the 'facts' are true or not.

Previous studies confirmed that honesty, fairness, and intelligence in conveying information are important traits that must be practiced in journalistic activities. Mohammad Saleh emphasized that media journalists also have an important role in conveying da'wa messages ${ }^{14}$. Therefore, the Qur'an and hadith are used as basic references for journalism ethics.

From the discussion in this introduction, it can be concluded that a journalist needs to put forward the truth through an honest, fair and balanced attitude in making news, and being smart

\footnotetext{
${ }^{7}$ Muchtar et al., "Journalism and the Islamic Worldview: Journalistic Roles in Muslim-Majority Countries."

${ }^{8}$ Ramli, "DAKWAH DAN JURNALISTIK ISLAM (Perspektif Dakwah Islamiyah)."

${ }^{9}$ Basyouni Ibrahim Hamada, “Towards a Global Journalism Ethics Model: An Islamic Perspectivet," Journal of International Communication 22, no. 2 (2016): 188-208.

10 Purnama, "Pemikiran Parni Hadi Tentang Jurnalisme."

${ }^{11}$ Steele, "Journalism and 'The Call to Allah': Teaching Journalism in Indonesia's Islamic Universities and State Institutes."

${ }^{12}$ Saragih, "Some Characteristics of Islamic Journalism Based on Al Quran."

${ }^{13}$ Hamada, "Towards a Global Journalism Ethics Model: An Islamic Perspective†."

${ }^{14}$ Mohamad Saifudin Mohamad Saleh et al., "Islamic Values in Environmental Communication within the Malaysian Media: A Case Study of Utusan Malaysia and Berita Harian," Jurnal Komunikasi: Malaysian Journal of Communication 37, no. 3 (2021): 54-72.
} 
in delivering news. Meanwhile, the courage that is the nature of Prophet Ibrahim has not been too highlighted. When a journalist already has truthful information without having the courage to convey it, then the activity cannot be said to be journalistic. Therefore, we want to fill this void by referring to the story and character of the courage of the prophet Ibrahim in the Qur'an as a reference for journalistic activities that gave birth to the latest research, namely prophetic journalism of the Prophet Ibrahim.

The purpose of this research is not only to introduce Ibrahim's prophetic journalism to Muslims, but also to foster a new spirit for journalists in practice. Thus, journalists are able to convey essential truths to the public. In the end, we hope that this research can serve as a reference for journalists to maintain their professionalism.

\section{B. Theoretical Review}

In this literature review, we write two subtitles. The first is the four characteristics of the Prophet Muhammad who are role model. Furthermore, we continue with the subtitle about how journalism is a step of da'wa in Islam.

\section{Four Traits of the Prophet Muhammad}

Prophetic journalism refers to the four prophetic traits of the Prophet Muhammad, including: șiddīq, amānah, tablīgh and fațānah. The four attributes are referred to from two sources of reference for all Muslims in the world, namely: Al Quran and Al Hadith.

\section{a. Siddiq}

When he was young, the Prophet Muhammad received the nicknames "șiddīq" and "amin" from the Quraysh community. Everyone greatly respected him without exception the leaders of Mecca. The nature of siddi $q$ which means being honest in word and deed is able to attract anyone who approaches him. Siddiq's nature is also able to build the trust of others with confidence and sincerity from honesty.

This honest characteristic is essential in the practice of journalistic activities where honesty is above anything else. Bill Kovach, for example, says that honesty is an important element to achieve the truth ${ }^{15}$. Honesty is the main principle in journalism, where it lies not only at the theoretical level but also in practice.

It is narrated that Prophet Muhammad SAW once called on his people to speak and act honestly in every situation. Wherever and whenever it is, honesty needs to be upheld. Ubaidullah Ibn Shamit r.a. reported that the Messenger of Allah (SAW) said, "Guarantee me six things from yourselves, I will guarantee heaven for you: be honest when you speak, keep what you promise, fulfill a mandate when you are entrusted with a mandate, guard your genitals, lower your gaze, and hold your hands," (Hadith Hasanm narrated by Ahmad 22251).

Based on the hadith above, if it is associated with the concept of prophetic journalism, then a journalist must write news that is true and what it is. A journalist's pen is analogous to being sharper than a sword. Therefore, whatever a journalist says can have an impact on the public, so journalists should convey the truth that is impartial.

In addition, what a journalist conveys must be accountable. The application of prophetic journalism must be supported by the existence of a journalist who is aware of the importance of working according to his conscience who follows the truth. It is because spreading the truth is not just about getting a salary and popularity. Spreading the truth is an obligation for everyone, especially journalists. Therefore, journalists are expected to have the courage to take risks to continue to uphold courage and justice ${ }^{16}$.

Efforts to realize the honest nature as applied by the prophet Muhammad are needed to achieve justice in the world of journalism. Justice in journalism is an attitude that is not selective

\footnotetext{
15 Tom Kovach, Bill; Rosenstiel, "NRJ Books: The Elements of Journalism: What Newspeople Should Know and the Public Should Expect," Newspaper Research Journal (2001).

16 Purnama, "Pemikiran Parni Hadi Tentang Jurnalisme."
} 
in seeking and disseminating information. It is a good thing that journalists can be honest, fair, and fully committed to telling the truth. Thus, they do not harm other parties and they are also responsible for the rights of citizens to know information.

A journalist upholds the principles of fair behavior in sorting and selecting news to be published. This is one of the spirits in one of the legendary principles of journalism, namely cover both sides. This concept is a principle that relates to the balance of all parties who are the object of news/information by covering more than one party involved in an event ${ }^{17}$. Journalists must be fair to all parties who are their objects, such as covering both parties involved. Thus, news can be written or work that is balanced or not inclined to certain parties.

McQuail says that justice which is also interpreted as balance is a 'neutral attitude' that must be achieved by journalists ${ }^{18}$. This is also a form of responsibility of a journalist. This is how the media can balance between freedom and values that live in the media environment, including a sense of justice and a sense of being properly managed. The balance through both parties is not only concerned with quantity, but also quality and problem orientation in the news must balance the freedom and the media market.

Still related to justice, Islam itself has regulated it in the Qur'an Surah An-Nisa verse 58 which means "Indeed Allah commands you to convey the mandate to those who are entitled to receive it. And when you set a law between people, think about it justly. Allah is the best who gives treatment. Indeed, Allah is All-Hearing, All-Seeing." When a journalist cannot be fair in publishing information or news, then they are included in the category of losers. In this context, journalists are called losers because they convey information that is not in accordance with the principle of honesty. Furthermore, the community is also harmed by receiving information that cannot be justified.

From the description above, it can be seen that the first professional trait is honesty. As for honesty itself has a close relationship with justice. The honesty carried out by journalists is justice for the interviewees and for the people who read books.

\section{b. Amānah}

The second characteristic of the Prophet Muhammad is trust. This trait means: can be trusted in carrying out their responsibilities. This noble character should be imitated by humans. Because, we as humans get a mandate from God to be His servants who can lead this earth ${ }^{19}$.

The nature of trust must be strived for, on the contrary, hypocrisy must be abandoned by humans as Allah SWT says in Surah al-Ahzab verse 24:

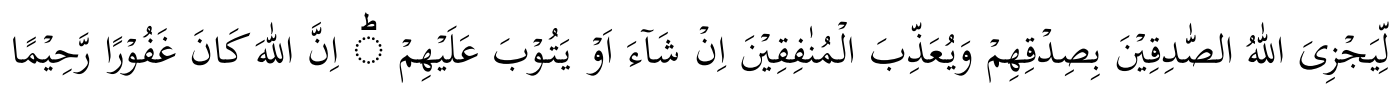

Meaning:

That Allah may reward the righteous for their righteousness and punish the hypocrites if He wills or accepts their repentance.

From the verse aforementioned, Allah SWT commands us as His servants to always be trustworthy. There is a real reward for those who are trustworthy. On the other hand, there is also a painful threat to the hypocrites who do not want to repent. This is a task that is also carried out by a journalist, where he has a great responsibility to be the eyes and ears of the community to convey news clearly and transparently.

Journalists are subjects in journalistic practice. Good and bad mass media is influenced by the quality of the news produced. A trustworthy journalist certainly supports the high quality of news and mass media. The trustworthiness of a journalist is also a sign of his professionalism.

\footnotetext{
${ }^{17}$ Halimatul Abkoriyah and Tribuana Tungga Dewi, “OBJEKTIVITAS BERITA DI HARIAN KOMPAS DAN KOMPAS.COM (ANALISIS ISI PEMBERITAAN KASUS PEMBUNUHAN ENGELINE)” 7, no. 2 (2017): 40-53. 18 Ibid.

${ }^{19}$ Sakdiah, "Karakteristik Kepemimpinan Dalam Islam (Kajian Historis Filosofis) Sifat-Sifat Rasulullah," Jurnal Al-Bayan 22, no. 33 (2016): 29-49.
} 
This is in accordance with the Journalistic Code of Ethics (JEC) Number 2 in Indonesia, namely Indonesian journalists take professional ways in carrying out journalistic duties.

\section{c. Tabligh}

Tabligh is one of the characteristics of the Prophet Muhammad which means conveying His commands and prohibitions. In his delivery, the Prophet Muhammad never hid or added verses of the Alqur'an that were conveyed to his people. The Prophet Muhammad respected the nature of this tabligh because what he conveyed had an impact on society.

The meaning of tabligh is to convey. A journalist has to convey news/information. The word "deliver" means that a journalist must be able to provide true news. He must be able to make sure there is no truth or fabricated information. In this case, journalists must convey any information that is the right of the public.

Journalists should not take any information for granted without going through the verification stage from the source. Verification shows the professional value for a journalist before delivering news ${ }^{20}$. Because, by doing this, journalists can ensure the truth and can be held accountable for the news that will be delivered. Ironically, Ishwara stated that currently, some journalists tend to be lazy to verify data due to time constraints, whereas for a journalist disciplined attitude in verifying news becomes the core of journalism activities ${ }^{21}$.

\section{d. Fațānah}

After siddiq amānah, and tabligh, the last trait that exemplifies Prophet Muhammad is fațānah. This nature means the ability to use the mind in determining what is right and wrong 22 . In the context of journalism, smart has the right meaning in reading the situation. Smart can also mean wise in processing information from the search process to news publications to the eyes and ears of the public. This fourth Prophet characteristic indicates that a journalist must have a long mind. He must understand the risks. Some say that fațannah in journalism means giving news full of wisdom ${ }^{23}$.

The nature of fatānah is the most important trait that must be possessed by a journalist. If a journalist already has an intelligent nature, then it can be ascertained that he is siddiq , tabligh, and trustworthy in writing information. Intelligence is a balancing value among Islamic values exemplified by the Prophet. An intelligent journalist understands how to search for information run smoothly to produce accurate news.

As previously explained, the meaning of the term prophetic often refers to the prophetic nature of the Prophet Muhammad. These qualities need to be emulated by other humans, including journalists. This is because as mentioned in the Qur'an Surah Al-Qalam (68:4) which explains how great the character of the Prophet Muhammad is "And indeed, you are (Muhammad) of a great moral character". From the verse aforementioned, we can see that the prophet Muhammad had morals that should be imitated by anyone.

\section{Journalism as Da'wa in Islam}

Da'wa is a form of communication for Muslims that contains messages of goodness. Over time, da'wa must also be in line with existing developments and conditions. Nowadays, people

\footnotetext{
${ }^{20}$ Ivor Shapiro, Patrizia Albanese, and Leigh Doyle, “What Makes Journalism 'Excellent'? Criteria Identified by Judges in Two Leading Awards Programs," Canadian Journal of Communication 31, no. 2 (2006): 425445.

${ }^{21}$ Luwi. Ishwara, “Jurnalisme Dasar" (2011): 188.

${ }^{22}$ Eni Setyowati, "Pendidikan Karakter Fast (Fathonah, Amanah, Shiddiq, Tabligh) Dan Implementasinya Di Sekolah" (2019): 2019.

${ }^{23}$ Dian Muhtadiah, "Peran Jurnalisme Profetik Menghadapi Hoax," Jurnal Dakwah Tabligh 18, no. 2 (2017): 181-200.
} 
tend to use mass media to get information. The development of the media makes demands for its generation to utilize and maximize the media as a means of da'wa ${ }^{24}$.

The presence of technology such as radio, computers, television, and the internet has an important role in the world of da'wa, but can also be an obstacle in preaching (Siddiq, 2019). Currently, the reality presented by the media to the public is not necessarily the actual fact. Journalists tend to dictate to us about reality instead of preaching reality. In line with this, a journalist must be able to take advantage of this phenomenon as a medium of da'wa to convey the truth $^{25}$.

Muslims need to realize that currently journalistic activities can be used as a tool to spread the truth ${ }^{26}$. Writing that contains a message of goodness or truth is matched with the term $d a^{\prime} w a$ bil qalam which also means da'wa by using a pen or da'wa in writing. This is in line with journalistic activities which both write information for dissemination ${ }^{27}$. Da'wa bil qalam is an effort to design propaganda-style news that can provide enlightenment to the public.

The presence of Islamic journalism in addition to functioning as a source of information, education and entertainment, is also a development of the Islamic mission, namely amar ma'ruf nahyi mungkar ${ }^{28}$. The meaning of this sentence is to uphold the truth and forbid what is wrong. To realize this mission, journalism plays a role as a means of Islamic da'wa by prioritizing the Qur'an and As-Sunnah as a reference starting from the process of covering to disseminating information ${ }^{29}$. The information contained has an important role in carrying out journalistic activities that prioritize enlightenment, awareness, and peace that adhere to the Qur'an and AsSunnah ${ }^{30}$.

In our opinion, da'wa journalism has the same spirit as the concept of Peace Journalism ${ }^{31}$. Peace journalism is a journalism concept that focuses on calling for peace ${ }^{32}$. It contains universal and inclusive values, such as justice, security, safety, harmony, tolerance, respect, solidarity for all people all of which are also owned by da'wa journalism ${ }^{33}$.

Both da'wa journalism and peace journalism are options. Editors and reporters must agree on what to report and how to report it. This needs to be considered because it can affect the impact of good or bad information on the community ${ }^{34}$. For example, when there is a conflict, journalists are required to write news that can quell the fire of hostility in society. For this reason, journalistic instinct is needed in assessing every news covered so that the news is suitable for public consumption 35 .

As a journalism activity based on the principle of peace, several things must be avoided in writing information or news. First, journalists must avoid being non-neutral. In writing a story,

\footnotetext{
${ }^{24}$ Andries Kango, “Jurnalistik Dalam Kemasan Dakwah,” Jurnal Dakwah Tabligh 15, no. 1 (2014): 105-114, http://journal.uin-alauddin.ac.id/index.php/tabligh/article/view/341.

${ }^{25}$ Lukman Hakim and Anisah Meidayanti, "Implementasi Jurnalisme Dakwah Dalam Media Online Islam: Analisis Isi Berita VOA-Islam.Com," Jurnal Komunikasi Islam 10, no. 1 (2020): 173-193.

${ }^{26}$ Choirul Mahfud, "Ideologi Media Islam Indonesia Dalam Agenda Dakwah: Antara Jurnalisme Profetik Dan Jurnalisme Provokatif," Jurnal Dakwah 15, no. 1 (2014): 1-18.

27 Kango, "Jurnalistik Dalam Kemasan Dakwah."

28 Ibid.

${ }^{29}$ Hakim and Meidayanti, "Implementasi Jurnalisme Dakwah Dalam Media Online Islam: Analisis Isi Berita VOA-Islam.Com."

30 Mahfud, "Ideologi Media Islam Indonesia Dalam Agenda Dakwah: Antara Jurnalisme Profetik Dan Jurnalisme Provokatif."

31 Andi Faisal Bakti dan Isabelle Lecomte, "The Integration of Dakwah in Journalism: Peace Journalism," Jurnal Komunikasi Islam 05, no. 01 (2015): 191.

${ }^{32}$ Ayu Usada Rengkaningtyas, "Jurnalisme Damai Dalam Kerukunan Antarumat Beragama (Analisis Framing Kompas.Com Terhadap Isu Rohingnya)," Jurnal Kajian Islam Interdispliner 2, no. 2 (2017): 6.

${ }^{33}$ Andi Faisal Bakti dan Isabelle Lecomte, "The Integration of Dakwah in Journalism: Peace Journalism." 34 Ibid.

35 Wahyu Khoiruzzaman, “Urgensi Dakwah Media Cyber Berbasis Peace Journalism,” Jurnal ilmu Dakwah 36 , no. 2 (2016): 316-334.
} 
journalists should not side with one group and also not corner other groups. Second, journalists must avoid writing information that depicts threats to other parties while not highlighting differences that could lead to division. Third, journalists need to avoid confrontational writing because it can corner one party, resulting in a prolonged conflict. A journalist is trusted to bring true news; therefore journalists must ensure that they are worthy of the trust of the audience. Journalists must work honestly, curiously, impartially, and thoroughly on what is obtained and disseminated ${ }^{36}$.

Meanwhile, da'wa journalism or can also be called Islamic journalism has the mission of realizing peace, as the purpose of the Islamic religion was revealed ${ }^{37}$. Islamic da'wa is a method to convey a message of goodness to the community. In practice, da'wa journalism must understand the contribution to the spread of Islamic religious values and the objectivity of journalism. Because, basically, da'wa journalism is peace journalism which contains the concepts of tabligh (information), taghyir (social change), khairu ummah (common interest), and akhlaq al-karimah (noble behavior). This concept is relevant to the goal of Islamic journalism as a means of conflict resolution by promoting Islamic teachings that are relevant to universal values ${ }^{38}$.

With the role of journalism as Islamic da'wa, the term prophetic journalism emerged. Prophetic journalism is the application of journalism as the spread of Islamic da'wa. This can be seen from the meaning of the word prophetic which means prophetic nature, which is also contained in the Qur'an and As-Sunnah. Prophetic journalism refers to the life of the Prophet Muhammad by reflecting his character and noble character, especially his behavior with followers of other religions. The hope is that readers can find enlightenment, education, peace and openmindedness to understand the essential content of the news ${ }^{39}$.

\section{Methods}

This is qualitative research using the ethnographic method. This method originally started from anthropology field which was used to understand society by describing the patterns of sociocultural activities of a group of people 40 (Siddiq \& Hartini, 2019). However, nowadays ethnographic methods are also used in other fields of science. The ethnographic method can also be referred to as field research. Researchers conducted participant observation as the most important data collection technique.

In this study, the researcher wanted to dig up information about the implementation of prophetic traits on campus journalists in the news production process. The researchers are campus journalists, including: Dwiki Iqbal Rahmawan who is a TV Da'wa crew and KPI Journal (Islamic Communication and Broadcasting) since 2019, Qhoirun Annisa who is an intern TV Da'wa crew since 2020, and Putri Ardelia Taufiqurrohmah who is also a member of the Da'wa crew TV since 2019.

The data from this study is the result of daily observations of researchers as campus journalists in carrying out the news production process with other campus journalists since September 2019. Researchers try to answer questions about how campus journalists implement prophetic traits in the news production process. Not only stopping at the observation stage but the data from this study were also enriched by interviews. In the ethnographic method, interviews are conducted openly and in-depth over a relatively long time. The ethnographic method has a

\footnotetext{
${ }^{36}$ Andi Faisal Bakti dan Isabelle Lecomte, "The Integration of Dakwah in Journalism: Peace Journalism."

37 Khoiruzzaman, "Urgensi Dakwah Media Cyber Berbasis Peace Journalism."

${ }^{38}$ Andi Faisal Bakti dan Isabelle Lecomte, "The Integration of Dakwah in Journalism: Peace Journalism."

${ }^{39}$ Mahfud, "Ideologi Media Islam Indonesia Dalam Agenda Dakwah: Antara Jurnalisme Profetik Dan Jurnalisme Provokatif."

40 Mohammad Siddiq and Hatini Salama, “ETNOGRAFI SEBAGAI TEORI DAN METODE," Kordinat: Jurnal Komunikasi antar Perguruan Tinggi Agama Islam 18, no. 1 (2019): 23-48.
} 
characteristic that is rich in descriptions, has a comprehensive and integrated nature and qualitative analysis to obtain public perceptions ${ }^{41}$ (Siddiq \& Hartini, 2019).

\section{Results and Discussion}

There are various kinds of journalistic media on campus, some are electronic media (television and radio), some are print-based and online. By what was stated in the method chapter, the subjects in this study were students who were members of the television media "Dakwah TV" and the online media "Jurnal KPI" at UIN Sunan Ampel Surabaya. This sub-chapter explains how these campus journalists apply the four prophetic traits when producing news.

Media Da'wa TV has a strict recruitment and promotion system. In the early semester, students can register on this medium as an apprentice crew. They must undergo the internship period for one semester. If their performance is good and has high integration, then they can be promoted to the permanent crew of Da'waTV. The contents of Da'wa TV are varied, this media has approximately five programs, including "Campus Report", "Life Motion", "Lifestyle", "Muslim Campus", and "Street Food".

The journal KPI is an online media initiative by students of UIN Sunan Ampel Surabaya. The contents of the journal KPI are news produced from the campus environment and outside UIN Sunan Ampel Surabaya. Currently, this media is in a vacuum because the initiator and several of his crew have graduated from college.

\section{Application of the Four Prophetic Traits in Producing News}

Based on participant observations that the researchers did, the prophetic traits of the Prophet Muhammad were carried out by campus journalists at UIN Sunan Ampel Surabaya. Every character, from șiddīq, amānah, tablīgh, fațānah is carried out by journalists who still hold the student status. How the campus journalists implement the four prophetic traits in the news production process, the researchers describe in the following discussion:

\section{a. Siddīq}

Șiddīq means true. Journalists who have șiddī characteristics are journalists who preach the truth. In producing news, the campus journalist crew strives to present the right message. Not only that, they also try to carry out the gathering process in the right way. This can be seen when Iqbal, who is a Dakwah TV crew, covers the Campus Report program. In September 2019, another crew member, Iqbal, covered demonstrations against RUU KUHP, UU KPK, RUU Pertanahan, RUU Ketenagakerjaan.

At first, in front of Surabaya DPRD building, Iqbal and two other colleagues were not allowed to enter the coverage area. This is because they are not professional journalists who have a press ID from the professional mass media industry. There were police and guards at the DPRD building who refused them to enter the building. However, because there was an alumnus of UIN Sunan Ampel Surabaya who was present as a reporter from one of the Islamic TV stations, Da'wa TV team was allowed to enter, with a note, only two people were allowed to enter.

Da'wa TV crew is willing to follow these regulations. The crew that entered the building were a camper and an editor, meanwhile, Iqbal waited outside. Some of the reasons behind the decision include: 1) complying with the requirements set out in the DPRD building; 2) maintain safety, considering the conditions in the location are very crowded and prone to conflict; and 3) considering the number of crew entering the building, namely two people. They feel that the amount is sufficient to make coverage.

What is done by Da'wa TV crew above is one form of practicing the nature of șiddìq. Iqbal and his friends carried out the reporting process correctly. When they were not allowed to enter, Iqbal did not force him to enter the coverage area. In terms of process, Da'wa TV crews have complied with journalistic etiquette, in which they carry out reporting transparently.

\footnotetext{
${ }^{41}$ Ibid.
} 
The agreement made by Da'wa TV crew is also true because they value their safety. By only involving two people to enter DPRD building, they are tantamount to reducing the possibility of conflicts that arise. In such an unfavorable atmosphere, divisions can easily arise because of protests from the protesters and the media.

The same thing was done by Anisa who is an intern crew of Da'wa TV. In November 2020, Annisa was assigned the task of covering the selection of a beauty contestant named Guk Yuk Sidoarjo. The event took place during a pandemic, where the committee limited guests. At that time, Anisa struggled to get good pictures for her coverage.

At the same time, Anisa saw Instagram Live showing the Guk Yuk Sidoarjo election process. Based on the existing rules, Annisa cannot use the video from Instagram Live because the committee from Guk Yuk Sidoarjo requires every journalist to only use official documentation from the committee. As the response, Anisa chose to forget the Instagram Live she found and rushed to contact the official Guk Yuk Sidoarjo committee.

When contacting the Guk Yuk Sidoarjo committee, Annisa stated that she wanted to be able to get pictures of the event. The committee also provided a Google Drive link containing photos from the beginning of the audition to the night of the grand final. Annisa uses the file in the Google Drive link as footage in a news show.

Annisa's decision is a form of practicing the șiddiq value. Annisa has followed the rules set by the owner of the event she covers. This keeps him from violating the source's right to refuse. The right to refuse is a right owned by the resource person when he does not want to be included in a journalistic report. The nature of șiddi $q$ is essential in the practice of journalistic activities where honesty is above anything else. Bill Kovach says that honesty is an important element to achieve the truth. Honesty is the main principle in journalism ${ }^{42}$.

\section{b. Amānah}

Amānah means being trustworthy. This is what campus journalists are trying to do, one of which is when editing videos about the selection of Guk Yuk Sidoarjo 2020. When editing videos, the committee of Guk Yuk Sidoarjo does not require campus journalists to include sources. However, the editorial team of Dakwah TV entrusted the editors with being able to insert news sources into each footage.

Apart from being a form of high integrity as a journalist, what Da'wa TV does is a form of practicing the nature of trustworthiness and journalistic code of ethics; where the media crew denounced plagiarism. Da'wa TV shows its intention to avoid plagiarism by showing the source in the footage. Although the inclusion of the source is not mandatory, the Da'wa TV crew is aware that what they are doing is proof that they can be trusted in implementing the journalistic code of ethics.

The implementation of the nature of trust can be seen when the Da'wa TV crew tries to make news according to the agreement with the party who has purchased the news program. It should be explained in advance that the campus news report program on Da'wa TV in mid-2021 was purchased by a government agency. Da'wa TV is the media partner of the institution located in Surabaya.

The MOU between Da'wa TV and the agency stipulates that journalist from Da'wa TV are obliged to produce 400 stories. This is a bombastic number, if it is done by the entire Da'wa TV crew who are on active duty, then each person will make about 50 to 100 news stories. Each story is about two to three minutes long and should all be finished in just a few days.

Although the amount of news is very large with very little processing time, the campus journalists fulfill their obligation to complete the news. They solve it by helping each other and doing overlapping work. Everyone can be a VO filling reporter and a video editor at the same time. This is done so that the news they are working on is completed and in accordance with the collaboration between the campus and the government agencies above.

42 Kovach, Bill; Rosenstiel, "NRJ Books: The Elements of Journalism: What Newspeople Should Know and the Public Should Expect." 
What campus journalists do is a form of trustworthiness. Even though the work they face is very tough, the campus journalists still try to do it well. There is no option to withdraw from the work, because the MOU has been signed. In the MOU, they will also get an honorarium in accordance with their respective jobs, so that what they do is a professional job and has a high responsibility. In this context, they are not seen as mere students, but also as professional journalists. The students showed their professionalism as well as their trustworthiness by completing their news videos completely and on time.

The nature of trust was also shown by Iqbal and the crew in the coverage of the dragon boat rowing competition. This competition is a series of festivals organized by Surabaya. This is a routine activity that is expected to boost the tourism sector in this city.

The producer and assistant producer of Da'wa TV required the crew on duty, including Iqbal, to arrive before the show started. The event starts at 08.00 while they are required to come at 06.00 WIB. They obeyed the instructions by being present at the location at exactly $6 \mathrm{am}$. By arriving on time, they can occupy a strategic location to take pictures. This is important to do, considering that they have to compete for locations with professional media crews.

\section{c. Tabligh}

The nature of tabligh has the meaning of conveying. Campus journalists carry out this tabligh character as an effort to voice the events they report on. Tabligh can be seen when journalists try to deliver quality news to their audiences.

Putri, accompanied by an editor named Rafika, once tried to cover events regarding the construction of Campus 2 of UIN Sunan Ampel Surabaya, which is located in Gununganyar District, Surabaya. In the process of obtaining news sources, Putri and Rafika face an extraordinary challenge for a student. At first, they wanted to dig up information about the development from the public relations officer of UIN Sunan Ampel Surabaya. However, upon meeting with the public relations officers, they were directed to go directly to the field or to the construction site of Campus 2 in Gununganyar. The princess and the editor went to the construction site for Campus 2 , but they were stunned when they arrived at the site, because there are no buildings at all there. In addition, there are no officers or craftsmen. The location they visited was still flat land, waiting to be built upon.

Even though Putri and Rafika did not get the information they wanted, they were determined to keep the public updated on the developments. They produce the news according to the events they face with a consequence: the results of the coverage are not in line with expectations and the news elements raised are incomplete. The news angle, which was originally going to be about "when" the building would be finished, turned into general information about UINSA, which will have Campus 2.

What Putri and Rafika did is a form of tabligh nature in which the two journalists tried to convey the facts needed by the public. In the production process, they try their best to complete the news. In fact, due to the difficulty in obtaining news sources, they are unable to present all of the news elements completely. Nevertheless, Putri and Rafika's determination to report the incident was achieved. News about the construction of Campus 2 of UIN Sunan Ampel Surabaya can be broadcast to the audience.

Verification is a very important stage for a journalist before delivering news. Because, by doing this, journalists can ensure the truth and can be held accountable for the news that will be delivered ${ }^{43}$. Annisa did the same thing. As a campus reporter, he is required to be able to report the most updated events. During the month of Ramadan, Anisa tries to convey messages related to Ramadan as well. This is an attempt by a journalist to be able to convey religious values at the right time. The news about pilgrimage to Sunan Ampel is special because it is broadcast during Ramadan, where in that month many people focus on worship activities.

Meanwhile, Iqbal, who is also a journalist from a media called journal KPI, also practices tabligh nature when producing news about campus. In this media, Iqbal not only writes hard news

\footnotetext{
${ }^{43}$ Ishwara, "Jurnalisme Dasar." 
but also soft news which is full of Islamic values. In one segment called qolbun salim, Iqbal through the Journal KPI provides a forum for lecturers to give tausiyah to students and the general public. The keynote speakers were senior lecturers from the Islamic Communication and Broadcasting study program, Faculty of Da'wa and Communication, UIN Sunan Ampel Surabaya. Some of them are Prof. Ali Aziz and Dr. Abdul Sattar.

In the program above, Iqbal and his friends are determined to be able to provide useful values to their audience. What's more, the tausiyah was published during the month of Ramadan, so the nuances became even more solemn to live with. Not only that, during the month of Ramadan, Jurnal KPI journalists also reported on the flow of going home, homecoming posts, and rest areas. Thus, these journalists try to convey things that are important for travelers to know when approaching Eid.

\section{d. Fațānah}

Fațānah is intelligent. It is something that journalists need to have, including campus journalists. This is because every news production practice has various obstacles or challenges. These obstacles need to be addressed intelligently so that the story can be conveyed to the audience properly. If it is related to the context of journalism, then an intelligent journalist understands how to find information smoothly so as to produce accurate news ${ }^{44}$.

The nature of fatānah is applied by campus journalists, for example, when Annisa and her fellow Da'wa TV crew received an offer to make hundreds of news stories from one of the government institutions in Surabaya. Government agencies that buy programs from Da'wa TV don't want these news stories to be included in the "Campus Report", the original program from Dakwah TV. They also do not want the news to be included in other programs. Finally, Da'wa TV crews discussed how to solve the problem. Aldi, a station manager who used to be the head of Da'wa TV, suggested that a new program be made specifically to accommodate news from the government agency. The idea was approved by the rest of the crew and they released a new, nonpermanent program called "Jatim Update".

What Da'wa TV crew did was a form of experience in practicing the nature of fatannah. On the one hand, they have to publish news from government agencies because of the MOU they have signed, in which Da'wa TV is the media partner of the agency. On the other hand, Da'wa TV cannot report all events related to the institution in Dakwah TV's permanent programs. As a result, the release of the new program "Jatim Update" became the best solution for them. By releasing the "Jatim Update", Da'wa TV can still fulfill its obligations as a media partner as well as work on their new program.

Furthermore, fațānah can also be seen when Dakwah TV intern crew proposes a report to the assistant producer. The proposed theme is the collapse of the roof of the building located in front of the Faculty of Da'wa and Communication. When they first presented the idea to the assistant producers, they had doubts about whether the idea was accepted, because they are worried that it will worsen the image of UIN Sunan Ampel Surabaya. However, it turned out that after the idea was submitted, their assistant producer agreed.

The Da'wa TV apprentice crew consisting of four people tried to formulate the best and most possible information gathering. After discussing, they decided to conduct interviews with academic division at the Faculty of Da'wa and Communication. The campus journalists asked on behalf of their media about the fate of the student motorbikes that were affected by the collapse of the roof of the building.

From interviews with faculty academics, campus journalists received information that the cause of the collapse of the building's roof was due to the weathering of the building's roof. Unexpectedly, the academic side stated that the faculty would provide compensation to students whose motorbikes were affected by the collapse of the building in front of the Da'wa and Communications Faculty.

${ }^{44}$ Diana Rivera-Rogel et al., "Media Competencies for the Citizenship Training of Teachers from Andean America: Colombia and Ecuador," Paideia 27, no. 66 (2017): 80-89. 
What the young journalists did above is a form of intelligence, where their fears turn into solutions that are beneficial for many parties. By doing the right interview technique, they get a good response from the sources they interview. The news not only conveys information to the public but also provides solutions for victims. Indirectly, they helped the students who were victims of the collapsed roof.

It was a smart effort because without a good interview technique, the interviewee may be angry because he is afraid that his name will be tarnished if it is reported. However, on the other hand, Dakwah TV journalists actually received positive feedback so that they could help the victims. It is indeed one form of the journalists intelligence.

\section{Courage as Complementary to the Nature of the Prophetic Journalism}

Courage is an attitude that emerges in the face of fear. Emotionally, humans have the potential for fear in living life. It takes a strong heart and great confidence in the face of fear to defend the truth, even when faced with the reality of conditions that are not in accordance with desire ${ }^{45}$.

The courage of Prophet Ibrahim is true courage. He was not afraid to face the polytheists in his tribe, even his own father. He always showed courage when preaching to his people to worship Allah SWT. His courage did not dim despite the danger threatening him.

As narrated in the Qur'an, Prophet Ibrahim was a figure who never gave up on seeking the truth when everyone opposed him. There is a verse in the Qur'an that tells how the struggle of Prophet Ibrahim in destroying idols to prove that the idol is not God. Then he was attacked by various questions until he was burned alive. Still, he revealed the truth without fear.

Q.S. Al-anbiya' [21]: 62

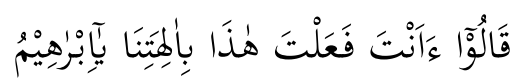

Meaning:

they asked, "Are you the one who did this (deed) to our gods, O Ibrahim?". Prophet Ibrahim did not stop to warn and warn his people. He saw his people in manifest falsehood and error. So, he found a way by destroying all the idols and leaving a large statue to be used as a lesson.

The nature of courage possessed by the Prophet Ibrahim can be an inspiration for journalists in upholding the truth. Because journalism itself is a practice of revealing facts or the truth ${ }^{46}$. Journalists do not mix facts and opinions ${ }^{47}$. Lying itself is contrary to the value of prophetic journalism.

Prophetic journalism is the spirit of journalism that adheres to honesty and truth based on conscience. The truth includes: the correct concept, the correct method of reporting, the correct communication pattern, the correct news production process, and the correct news product. The researcher argues that the concept of prophetic journalism needs to include an element of courage in it. Because the truth can be revealed by a journalist if they dare. One example is when Iqbal and other Da'wa TV journalists ventured to report the collapse of the roof of the building at UIN Sunan Ampel. If they prioritize fear over courage, then the news will not be published.

A strong commitment to convey the truth through journalism is the fundamental basis of the relationship between journalistic media and their readers ${ }^{48}$. The practice of journalism that

\footnotetext{
45 Zaimudin Zaimudin, “Karakter Nabi Ibrahim AS Dalam Al-Qur'an,” Jurnal Al-Fanar 1, no. 1 (2018): 3574.

46 Mozahir Salomão Bruck, "Journalism in Reconfiguration: Notes on Contracts and Contracting," Brazilian Journalism Research 15, no. 2 (2019): 418-437.

47 Moh Rosyid, "Membingkai Sejarah Pers Islam," At-Tabsyir 1, no. 1 (2013): 1-18.

48 Bruck, "Journalism in Reconfiguration: Notes on Contracts and Contracting."
} 
refers to the nature and story of the prophet Ibrahim can be applied to the concept of prophetic journalism, because journalists must think intelligently and critically ${ }^{49}$.

\section{E. Conclusion}

The results of this study indicate that campus journalists implement the four characteristics of the Prophet Muhammad, namely șiddīq, amānah, tablïgh, fațānah, when carrying out the news production process. In its implementation, prophetic traits can be overlapped. An event can represent two prophetic traits at once, such as when a campus journalist tries to report an incident with a government agency as a media partner. In this moment, campus journalists apply the nature of trust as well as fațānah. In addition, we initiate "brave" or "courage" nature of the Prophet Ibrahim as a complement to the four characteristics of prophetic journalism. Prophet Ibrahim's courage in conveying the truth, even though it was opposed by those around him, deserves an example for a journalist. The presence of a "bold" prophetic nature for journalists will increase the confidence of journalists to publish news according to reality. The implementation of prophetic traits can be done to maintain journalist professionalism. It is because by applying prophetic journalism, journalists are also upholding journalistic ethics, which requires journalists to be honest, balanced, and courageous in presenting facts. With the idea of prophetic journalism, it is hoped that it will create a professional and peaceful journalistic environment.

\section{References}

Abkoriyah, Halimatul, and Tribuana Tungga Dewi. "Objektivitas Berita di Harian Kompas dan Kompas.Com (Analisis Isi Pemberitaan Kasus Pembunuhan Engeline)” 7, no. 2 (2017): 4053.

Andi Faisal Bakti dan Isabelle Lecomte. "The Integration of Dakwah in Journalism: Peace Journalism." Jurnal Komunikasi Islam 05, no. 01 (2015): 191.

Bruck, Mozahir Salomão. "Journalism in Reconfiguration: Notes on Contracts and Contracting." Brazilian Journalism Research 15, no. 2 (2019): 418-437.

Eni Setyowati. "Pendidikan Karakter Fast (Fathonah, Amanah, Shiddiq, Tabligh) Dan Implementasinya Di Sekolah” (2019): 2019.

Hakim, Lukman, and Anisah Meidayanti. "Implementasi Jurnalisme Dakwah Dalam Media Online Islam: Analisis Isi Berita VOA-Islam.Com." Jurnal Komunikasi Islam 10, no. 1 (2020): 173193.

Hamada, Basyouni Ibrahim. "Towards a Global Journalism Ethics Model: An Islamic Perspectivet." Journal of International Communication 22, no. 2 (2016): 188-208.

Ishwara, Luwi. "Jurnalisme Dasar” (2011): 188.

Kango, Andries. “Jurnalistik Dalam Kemasan Dakwah.” Jurnal Dakwah Tabligh 15, no. 1 (2014): 105-114. http://journal.uin-alauddin.ac.id/index.php/tabligh/article/view/341.

Khoiruzzaman, Wahyu. "Urgensi Dakwah Media Cyber Berbasis Peace Journalism." Jurnal ilmu Dakwah 36, no. 2 (2016): 316-334.

Kovach, Bill; Rosenstiel, Tom. "NRJ Books: The Elements of Journalism: What Newspeople Should Know and the Public Should Expect." Newspaper Research Journal (2001).

Mahfud, Choirul. "Ideologi Media Islam Indonesia Dalam Agenda Dakwah: Antara Jurnalisme

${ }^{49}$ Muchtar et al., "Journalism and the Islamic Worldview: Journalistic Roles in Muslim-Majority Countries." 
Profetik Dan Jurnalisme Provokatif." Jurnal Dakwah 15, no. 1 (2014): 1-18.

Mohammad Siddiq, and Hatini Salama. "Etnografi sebagai Teori dan Metode." Kordinat: Jurnal Komunikasi antar Perguruan Tinggi Agama Islam 18, no. 1 (2019): 23-48.

Muchtar, Nurhaya, Basyouni Ibrahim Hamada, Thomas Hanitzsch, Ashraf Galal, Masduki, and Mohammad Sahid Ullah. "Journalism and the Islamic Worldview: Journalistic Roles in Muslim-Majority Countries." Journalism Studies 18, no. 5 (2017): 555-575.

Muhtadiah, Dian. "Peran Jurnalisme Profetik Menghadapi Hoax." Jurnal Dakwah Tabligh 18, no. 2 (2017): 181-200.

Purnama, Feri. "Pemikiran Parni Hadi Tentang Jurnalisme." Communicatus: Jurnal Ilmu komunikasi 3, no. 1 (2019): 33-48.

Ramli. "DAKWAH DAN JURNALISTIK ISLAM (Perspektif Dakwah Islamiyah)." KOMUNIDA: Media Komunikasi dan Dakwah 5, no. 1 (2015): 13837-138660-30.

Rengkaningtyas, Ayu Usada. "Jurnalisme Damai Dalam Kerukunan Antarumat Beragama (Analisis Framing Kompas.Com Terhadap Isu Rohingnya)." Jurnal Kajian Islam Interdispliner 2, no. 2 (2017): 6.

Rivera-Rogel, Diana, Ligia I. Zuluaga-Arias, Nélida María Montoya Ramírez, Luis M. RomeroRodríguez, and Ignacio Aguaded. "Media Competencies for the Citizenship Training of Teachers from Andean America: Colombia and Ecuador." Paideia 27, no. 66 (2017): 80-89.

Rosyid, Moh. “Membingkai Sejarah Pers Islam." At-Tabsyir 1, no. 1 (2013): 1-18.

Sakdiah. "Karakteristik Kepemimpinan Dalam Islam (Kajian Historis Filosofis) Sifat-Sifat Rasulullah." Jurnal Al-Bayan 22, no. 33 (2016): 29-49.

Saleh, Mohamad Saifudin Mohamad, Shaidatul Akma Adi Kasuma, Mark Harris Zuknik, and Nik Norma Nik Hasan. "Islamic Values in Environmental Communication within the Malaysian Media: A Case Study of Utusan Malaysia and Berita Harian." Jurnal Komunikasi: Malaysian Journal of Communication 37, no. 3 (2021): 54-72.

Saragih, M. Yoserizal. “Some Characteristics of Islamic Journalism Based on Al Quran.” Budapest International Research and Critics Institute (BIRCI-Journal): Humanities and Social Sciences 1, no. 1 (2018): 1-10.

Shapiro, Ivor, Patrizia Albanese, and Leigh Doyle. "What Makes Journalism 'Excellent'? Criteria Identified by Judges in Two Leading Awards Programs." Canadian Journal of Communication 31, no. 2 (2006): 425-445.

Steele, Janet. “Journalism and 'The Call to Allah': Teaching Journalism in Indonesia's Islamic Universities and State Institutes." International Journal of Communication 6, no. 0 (2012): 18.

Zaimudin Zaimudin. "Karakter Nabi Ibrahim AS Dalam Al-Qur'an." Jurnal Al-Fanar 1, no. 1 (2018): $35-74$. 